\title{
Instead of an Introduction: Medieval Europe Translated
}

\section{Pavlína Rychterová*}

In the years 2011-2017, the ERC Project "Origins of the Vernacular Mode. Regional Identities and Textual Networks in Late Medieval Europe (OVERMODE) « was carried out at the Institute for Medieval Research of the Austrian Academy of Sciences. The project addressed Central and Eastern Central Europe and focused on the formation and transformation of vernacular mentalities, especially on the transfer of a theological body of knowledge into various vernaculars in the late Middle Ages. One aspect of the project was a collaboration with colleagues from the Department of Byzantine Studies, in which a transcultural approach was developed. Results were presented in a series of sessions on the ideology of translation at the International Medieval Congress in Leeds in 2013. Individual papers concerned politics, "professional « translators and the cultural dynamics of translations. ${ }^{1}$ Lively and productive discussion following the individual papers led to an agreement among the participants to pursue the comparative approach further, which was then carried out in the years 2013-2017 within the framework of the COST Action IS 1301 "New Communities of Interpretation. Contexts, Strategies, and Processes of Religious Transformation in Late Medieval and Early Modern Europe« and in collaboration with the research network of the Cardiff conferences on the theory and practice of translation in the Middle Ages (The Medieval Translator). ${ }^{2}$ In the Journal "Medieval Worlds « we found an appropriate platform to pursue further the debate on medieval translation cultures. In the present issue, a first group of articles focusing on various aspects of medieval translation are collected, and further clusters will extend the scope in future issues of the journal. The following introductory essay will address some of the research problems on medieval cultures of translation. Rather than summing up the individual articles presented in the following, it returns to the research on medieval Latin Europe pursued in the ERC Project which stood at the beginning of our engagement with the issue of translation.

* Correspondence details: Pavlína Rychterová, Institute for Medieval Research, Austrian Academy of Sciences, Hollandstraße 11-13, 1020 Vienna, Austria; email: pavlina.rychterova@oeaw.ac.at.

1 www.imc.leeds.ac.uk/imcarchive/2013/sessions/130/ (/131 and /132).

2 The 11th Cardiff conference took place in Vienna in March 2017, see Rychterová and Odstrčilík, Medieval Translations. 


\section{Translating Societies}

In the year 2007, when Peter Burke edited a volume ${ }^{3}$ including his programmatic article on cultural translation in Early Modern Europe, the practice of (cultural) translation moved into the focus of historiography, especially in Medieval Studies. The broad scope of the article from purely linguistic towards cultural translation opened up new possibilities for analysis, and made material which was often very well known to generations of philologists appear new and unexplored. As Mareike Menne observed in her review, ${ }^{4}$ there is little distinction between translation of cultures and cultures of translation of texts in this volume. Both terms appear as subsidiary in the approach of Burke, Hsia and their contributors. This merging may be regarded as methodologically questionable, but it relieves the researcher of strict and conservative disciplinary boundaries and allows him or her to formulate questions targeting the social whole, social transformations and their legacies contained in the language of individual textual witnesses. Articles in Burke's and Hsia's volume analysed European as well as non-European early modern material, but historians of the European Middle Ages felt encouraged by the approach which relied so strongly on an interdisciplinary collaboration. The authors challenged nationally defined philologies, which had split the study of medieval material into several specialized thematic and methodological discourses. This enabled the development of a common approach, which may define new common ground for research on the abundantly transmitted, often cumbersome multilingual medieval textual material.

The European Middle Ages may be regarded as very conscious of the role of languages in society. As Patrick Geary pointed out, "Language, then, is only one of the cultural artifacts that under specific circumstance can be mobilized (one is attempted to say 'weaponized') for political action «. ${ }^{5}$ As such, languages, their use and the methods of their distinction represent a research topic which may help us to achieve a better understanding of processes of political decision making, of the construction of political or cultural loyalties (among others strategies of social inclusion and exclusion), as well as of processes of formation and transformation of collective identities. The historical dimension of modern European languages is related to the Middle Ages. The history as well as the interpretation of the Middle Ages reflected back on the research on these languages since the nineteenth century. Back then an approach was formulated which merged romantic representations of the European Middle Ages, modern political claims of distinct social groups using individual languages as the vehicle of the right of self-determination, and newly developed methods of textual criticism which had to guarantee the "scientific " validity of the resulting narratives on the origins of European peoples and their languages. The peoples and languages in focus were nevertheless not ancient but modern, which has trapped the research on their ancient and medieval predecessors in a flawed hermeneutic circle. Not least because of this research, especially by the nationally defined philologies, "we have come to think of linguistic communities as somehow natural, even primordial, and we take it for granted that the history of the linguistic diversity of Europe from antiquity to the high Middle Ages is indicative of the history of Europe's people«, as Patrick Geary put it. ${ }^{6}$ Geary interestingly excludes the late Middle Ages from his reasoning 
on the character of our understanding of European languages, although the relevant late medieval material at our disposal is incomparably richer and more diverse than the textual witnesses transmitted to us from previous centuries. The reason for this exclusion may be the character of the traditional but still powerful narratives on the medieval origins of modern European languages on which Geary focused. Nationally-defined philologies tried to trace their own, highly-developed literary languages as early as possible into the high or even early Middle Ages. Consequently, they made great efforts to justify an early dating of language material contained in late medieval textual witnesses. This effort entailed the need to ignore the genuine character of this late medieval material, and more or less to ignore the late Middle Ages as a specific period with its own literacy and its own political aims, in which languages played various roles. Only the origins mattered. ${ }^{7}$ The scarcity of relevant early and high medieval vernacular material opened a space for the dominance of speculation over textual evidence and made the formulation of simplified and straightforward narratives possible. In consequence, one particular role, one particular purpose, one particular function among the many which these languages fulfilled in the respective times, places, and societies came to be highlighted.

Therefore, assessing the history of the roles European languages played in the self-understanding of medieval societies has to start with consideration of the histories of modern European philologies. Of the many available, Patrick Geary has chosen the Slavonic ones. ${ }^{8}$ The history of political instrumentalizations of lingua slavonica (or linguae slavonicae), which were woven into the fabric of the research on these languages from the very beginning, shows how persistent particular narratives may be. It demonstrates how important the languages, as vehicles of collective identity, may be and are for a society, in the past as well as in the present; and how dominant the narratives on them may be and are among the strategies of identification that European societies have negotiated and negotiate in the past and in the present. The example of the Slavonic languages shows how problematic it is to challenge these narratives - when they fall, great parts of the self-understanding of the respective societies will be cast into question, which is something these societies, for the most part, are not yet ready to permit.

The weight that modern political demands during the formation of national identities put on individual European vernacular languages shaped not only the modern philologies but also our perception of the past and our ideas on how to interpret the stories transmitted from this past. Being aware of this problem nevertheless does not help us replace these stories with new ones. An inevitable requirement here is an examination of available sources, abstaining from preconceived interpretative models. The context and the discourse in which the individual texts are embedded has to be reconstructed in as much detail as possible. Texts transmitted to us in more than one copy, in more than one version, are regarded, for good reason, as particularly valuable. This is all the more valid for texts transmitted in more than one language. They make it possible to reconstruct the semantic as well as the sociolinguistic context of individual words, phrases, and expressions as a translator understood them. The question is how we can transform this particular knowledge about language/s into a narrative about society and the roles the languages played in them. 
We usually resort to comparison in the hope that we will then be able to hierarchize the plethora of information contained in the source material according to the different significance and weight accorded to it in different cultural settings. Comparison, which »can help to defamiliarize the familiar " ${ }^{9}$ is nevertheless a delicate matter, as Jürgen Kocka and Heinz-Gerhard Haupt have stressed. A comparative method has to be multi-layered ${ }^{10}$ and take not only the material itself and its original context into account, but also the context of the research on this material, individual theoretical and methodological approaches, their interactions in time and their varying influence on the final interpretative framework. Of the methodological issues defining the comparative effort, the most interesting one is to ask "whether the comparison undertaken today by the historians already has been practiced by contemporaries in the past. Very often societies are defining themselves in relation to or against other societies. ${ }^{11}$ In any translation, a comparison is intrinsic - to compare historical phenomena, languages, texts, etc. in fact means translating them, in order to understand their meaning within our own frame of reference. We have to be very careful, of course, that their original meaning does not get lost during this operation. This can only be achieved through a constant hermeneutic effort, which means that any research result we formulate, any knowledge we win by the examination of sources, has to be regarded as only preliminary.

Translation as a theoretical concept and a methodological tool is a complex approach. First, the concept of translation is inseparable from the concept of culture in the same way as the concept of comparison is inseparable from it. With the expansion of cultural studies - to which Peter Burke's approach mentioned at the beginning of this essay is related -, the concept of translation was stretched beyond the linguistic discipline of translatology which had first formulated its points of reference. Roman Jakobson, with his concept of intra-lingual, inter-lingual and inter-semiotic translation, opened the door to a culturology-based understanding of translation. ${ }^{12}$ His approach was further discussed and broadened by, among others, Umberto Eco, who defined translation as an art of interpretation of semiotic systems. ${ }^{13}$ On the one hand, this broadening of the concept of translation increased its applicability; on the other hand, it diminished its terminological edge. As Peeter Torop put it:

... it should be added ... that translation itself is a concept that is extremely loaded methodologically. Still the fact that translation as a concept is loaded does not mean it is metaphorised. Translation and translating are concepts concurrent with an active culture and allow us in the situation of the scarcity of culture theoretic means to approach the essence of cultural mechanisms in a way that the analysis of both translation and translating as well as culture are enriched. ${ }^{14}$

9 Kocka and Haupt, Comparison and beyond, 4.

10 Kocka and Haupt, Comparison and beyond, 14: "One cannot compare phenomena in their multi-layered totality - as complete individualities - but only in certain regards. Comparison thus assumes to some degree a selection, abstraction, and detachment from context. (...) In other words, comparison always means abstraction."

11 Kocka and Haupt, Comparison and beyond, 16.

12 Jakobson, On linguistic aspects of translation.

13 Eco, Experience in Translation.

14 Torop, Translation as translating culture, 603; Pym, Exploring Translation Theories, 139. According to Pym the term »translation « was appropriated by various disciplines in a "willfully metaphorical« manner. Cf. also Woodsworth and Lane-Mercier, Introduction. 


\section{The Bible and the Vernaculars}

Medieval European societies sharing Latin written culture may be defined as translating societies. Interlingual translation concerned mainly Latin on one side and the so-called "vernaculars " on the other side. Terminology is an issue here: the German translation of the English term "vernacular" is Volkssprache (»language of the people«), whereas, for example, the Czech translation goes even further: národní jazyk means »the language of the nation«. It is therefore not easy to "translate" the idea of the vernacular from one research context (nationally defined historiographies, linguistic sciences, and philologies) into another. The functions which the vernacular languages fulfilled in individual medieval societies varied over time. In some cases the terms "national« or "people's " language may actually be more appropriate than the term "vernacular". In Bohemia, in the second decade of the fourteenth century, a vernacular Czech chronicle was written, containing passages which have been interpreted by František Graus in his influential analysis as one of the first, genuinely pre-modern definitions of a "national« language. ${ }^{15}$

Although medieval societies were, from time to time, inclined to regard one or the other vernacular language as a crucial element of collective identity, such attributions were by no means long-lasting and/or stable. The absolute majority of vernacular texts extant from the Middle Ages concerns religious education, and as such had a pragmatic purpose - to reach social groups uneducated in Latin with a basic (and later more complex) religious message. Discussions accompanying these efforts usually included various attempts to define the role and value of the (respective) vernacular language in the (respective) society, attempts which relied on biblical as well as late antique authorities; of these, the narrative of the Tower of Babel embedded in various forms of exegetic reflection was the most virulent. ${ }^{16}$

The translation of the Bible plays a specific, and in many aspects the most important role in the history of medieval translation. Vernacular Bibles had the potential to elevate the target language to a new level of dignity in the eyes of its users. The reasons for the many translations of the biblical text were, in the first place, purely devotional. They were often aimed at noble ladies in religious orders - the Book of Psalms belongs to the earliest biblical books translated into European vernaculars in the Middle Ages, and the most frequently translated ones, together with the Gospel of Matthew. In the second half of the fourteenth century, complete translations were made in several European vernacular languages - German, Czech, and English; complete French and Castilian translations had appeared several decades earlier. ${ }^{17}$ With the dissemination of the printing press, the complete vernacular $\mathrm{Bi}$ bles were successively printed in all European vernacular languages, laying the foundation for their later codification - for example, the so-called Kralice Bible, a complete humanistic Czech translation from Hebrew, Aramaic and Greek models made at the end of the sixteenth century, which served as a basis for the codification of the standard Czech language elaborated by a group of nationalistic Czech philologists in the first half of the nineteenth century. see Rychterová, Chronicle of the so-called Dalimil.

16 For the medieval exegesis of the Tower of Babel narrative, see the still unsurpassed Borst, Turmbau von Babel.

17 On the late medieval vernacular translations of the Bible, see Solopova, Wycliffite Bible. 
Although the reasons for individual Bible translations varied, the effort to make the Bible accessible for non-professionals was, from the beginning, an issue of power. The first medieval »vernacular « translation of the Bible appeared in the fourth century with Jerome's Latin and Wulfila's Gothic translation, aimed at the priestly elite, which was attempting to make the Christian liturgy comprehensible for newly-Christianized peoples. ${ }^{18}$ The "vernacularization « of the Bible represented a part of the struggle for control of Christian teaching in the fourth century, when the "Arian « heterodoxy was an issue in the time and place where the Gothic translation originated. In the ninth century, Slavonic translations of biblical material accompanied by a newly invented script again served as a means in the fight for dominance in newly-Christianized areas in the Carpathian Basin between the Frankish Church, the Roman papacy and the Byzantine Empire. ${ }^{19}$ In the twelfth century, Peter Valdés drew upon the Bible to formulate his heterodox teachings aimed at lay people and directed against the professional elite, the hierarchic church. In reaction to the spread of Valdensian heterodoxy, the papacy tried to prohibit the translations of the Bible, so the interpretation of scripture would stay in their hands. Nevertheless, the more the Church hierarchy departed from the ideal of the New Testament (Apostolic) Church in the eyes of its critics, the more the message of the Scripture became politically charged. When, two hundred years after Valdes, John Wyclif formulated his own concept of Church reform, he regarded the secular lords, i.e. the laymen, as the guarantors and executors of the reform. The complete English translation of the Bible originated in the milieu of the noble supporters of Wyclif's ideas, who formed a significant opposition to the institutional Church. ${ }^{20}$ In Bohemia, some fifty years later, the noble supporters of Jan Hus and of his Wycliffite reform ideas commissioned prestigious copies of the Czech translation of the Bible, which they regarded, so it seems, as a statement of their own leading role in the future reformed Church. ${ }^{21}$ Hussite reformers regarded the Bible as the only guidance in their reform effort, and the vernacular language as the medium in which the reform had to be spread. Vernacular language played an important role in the formation of the reform party which defined itself as "the true and rightful Czechs", a definition mirroring the initially quite academic debate at the University of Prague between masters, in the main members of the Artistic Faculty belonging to the Czech nation of the university who supported Wyclif's universalist philosophical approach, and nominalist masters, in the main belonging to the Theological Faculty and to the Saxon, Bavarian and Polish nations at the university (who were mostly German-speaking inhabitants of Silesian principalities). 


\section{Translatio studii et imperii}

Czech reformers elevated the vernacular language, but they did not have to translate the Bible for the purpose, in contrast to their English paragons. A full translation of the Bible had been available in Czech already half a century before Hussite theologians formulated the first elements of their reform approach. It was very probably commissioned by Emperor Charles IV and executed by a group of Dominican translators in the 1360 s. Although active participation by the emperor in the translation is disputed in the research and by no means certain, it is a very probable hypothesis because it makes sense in the context of similar well-evidenced activities of Charles IV. All of them were aimed at the elevation of the Czech language, which, nevertheless, was not defined as Czech in this context, but as Slavonic. The emperor had chosen the "Slavonic « language as an important strategy of identification for all the diverse inhabitants of his increasing domain, which he called the Lands of the Bohemian Crown and in which people with various regional, linguistic and historical identities lived. This Slavonic language included besides medieval Polish and Czech (the only distinct medieval Slavonic languages in the 14th century Latin Europe) very probably also eastern and south European Slavic languages. The emperor founded an abbey in Prague for which he obtained papal permission to perform the liturgy in Church Slavonic. In the scriptorium of the abbey several translations were made, including, among others, of the Historia scholastica by Peter Comestor, a very popular medieval rendering of the Bible especially suitable for lay readers. ${ }^{22}$ This translation was written in the Glagolitic script in Czech, not in Church Slavonic. It is therefore questionable for what purpose the translation was made. We may assume that the group of possible readers was very, very small, actually practically non-existent, as the abbey was staffed by Croatian monks proficient in Church Slavonic as well as in the Glagolitic script, but not in the Czech language. In Bohemia the Glagolitic script had been used in the tenth and eleventh centuries, which is evidenced by a few extant texts containing the oldest legends of St Wenceslas and Ludmila. However, after the abbey in Sázava was taken over by Latin Benedictines at the end of the eleventh century, the use, knowledge and even the memoria of Slavonic literacy disappeared in Bohemia. Charles IV revived the lost tradition; he supported the cult of St Jerome in his role as a translator of the Bible into Slavonic, as well as the cult of the Slavonic missionaries Constantine and Method, who had introduced the Slavonic liturgy in the Carpathian Basin in the ninth century. Finally, Charles IV commissioned a chronicle in which the Slavonic identity was defined as the original and common identity of the inhabitants of the Lands of the Bohemian Crown (including the newly incorporated principality of Brandenburg). ${ }^{23}$

What purpose did the Czech-Glagolitic translations from Latin made in the second half of the fourteenth century have, if not to mediate new contents to new recipients? Here the context of the representation of rulership has to be considered, which was present in medieval Europe, although it took different forms at various times and in various places. The concepts of translatio imperii and translatio studii had been present in the Latin medieval 
culture since the (symbolic) restoration of the Roman Empire by the Frankish king Charlemagne. The four empires defined in the biblical Book of Daniel preceded the Second Coming and thus determined the course of history. In the exegesis of the Book of Daniel, the fourth (and last) empire was identified with Rome, and as such it was firmly rooted in the European eschatological and political discourse from the early Middle Ages till the Napoleonic Wars. During the Middle Ages it was an integral part of the discourses of rulership representation, especially in the Holy Roman Empire and in France. It received a boost in the apocalyptical discourse which became virulent after the bubonic plague that reached Europe in the middle of the fourteenth century. In this discourse the idea of translatio imperii was crucial. Individual authors had previously taken on the challenge of interpreting the Book of Daniel in an effort to find a clue for the time of the Second Coming, among them, Adso of Montier en Der, Otto of Freising, Chrétien de Troyes, but especially Joachim of Fiore and his followers from among the Franciscan Spirituals. In the second half of the fourteenth century, the interpretations of John of Rupescissa were the most popular. ${ }^{24}$ All these authors searched for the signs of the Second Coming and tried to interpret contemporary polities on the basis of the Book of Daniel. The fourth empire was predominantly identified with the Roman Empire, sometimes with France, and less frequently with other ambitious European polities. All these interpretations spread through the medium in the anonymously transmitted and very popular genre of prophecy (ascribed to various Sibyls for example), and, as such, became an integral part of the European rulership discourse.

Individual European polities relied on, and instrumentalized the concept of translatio imperii ${ }^{25}$ in various ways, they emulated each other in their efforts, and re-interpreted the approaches borrowed from each other so that these would be appropriate in the competition for political dominance and ideological influence. The stylization of the Glagolitic-Slavonic/ Czech language as a strategy of identification for the people joined under the rule of Emperor Charles IV pointed towards the Fourth Empire of Daniel, an empire which in this particular interpretation should also include the areas of Slavic Orthodoxy. It reverted to the original idea (formulated during the mission of Constantine and Method) of a Slavonic realm. A complete translation of the Bible into Czech, the Czech translation of the Historia scholastica written in Glagolitic script, the translation of the Life of St Jerome into German and Czech simultaneously, ${ }^{26}$ and also the foundation of the University of Prague may be understood as loosely connected individual elements of the specific implementation of the concept of translatio studii in late medieval Bohemia complementary to the concept of translatio imperii. At the same time as Charles IV was designing his policies of rulership representation, several intellectuals at the court of Charles V of France, called the Sage, were working on a very similar concept, an integral part of which was the translation of crucial philosophical and political texts of Greco-Latin literary culture into French. ${ }^{27}$ We may assume that the French

24 John of Rupescissa, Vade mecum in tribulatione, ed. Tealdi = ed. Lerner and Rychterová.

25 See, on this concept, the old-fashioned but rock-solid Goez, Translatio imperii.

26 Černá, Hieronymus-Briefe des Prager Kanzlers.

27 Gilbert Ouy, Humanism and nationalism in France; Richter Sherman, Imaging Aristotle; Berman, Translatio studii. 
and Roman imperial courts influenced each other in their efforts. ${ }^{28}$ Charles IV's translation policies were further emulated and reinterpreted at the court of the Habsburg dukes, who appointed masters from Paris to their newly founded university in Vienna in direct competition with the University of Prague. In this milieu, a number of handsome, representative manuscripts originated, destined for the ducal court and containing newly made German translations of political and philosophical Latin works. The works of the so-called Viennese school of translators may be regarded as influenced by the same effort, although for the most part they were not directed at the ducal court but at various addressees, and did not contain any explicit statements aiming at the concepts of translatio studii et imperii. Their explicit purpose was, in the main, an improvement of religious lay education. ${ }^{29}$

\section{Lay Theology}

Religious educative texts (homiletic works included) represent the largest group of texts translated from and into languages used in Latin Europe in the Middle Ages. Especially from the twelfth century onwards, translation activity in this area increased exponentially, as compared to previous centuries. The flourishing of cities brought along differentiated literary cultures as well as differentiated approaches to Christian catechesis, trying to meet the varying demands of a steadily increasing number of urban inhabitants. With increasing urban prosperity, literacy gradually became more common among urban populations. The willingness of the economically successful burghers to share their wealth with Church institutions stimulated the latter to compete for the favour of the believers, and this not only among themselves: in urban environments, heterodox ideas spread very quickly. Many high- and late-medieval dissident religious leaders, among others, Peter Valdés, Geert Groote, Jan Hus, or Girolamo Savonarola, started their careers as popular preachers and religious leaders in prosperous medieval cities. From the middle of the thirteenth century, the newly established orders of Dominicans and Franciscans started to focus on the cities and towns in Latin Europe, and the competition of the individual institutions became more complex and more ruthless. An exchange of (verbal) blows between the parish priests and the mendicants was a common phenomenon in many European towns and cities, and it contributed to the loss of authority of the institutional Church, and stimulated the self-initiative of the urban laity in the search for individual paths to salvation. Sympathetic clerics accommodated the wishes of their flocks and provided them with crucial elements of Christian teaching formulated in their own vernaculars.

Translations and adaptations from Latin formed the basis of this lay teaching, and increasingly provided ever more loose adaptations and compilations. From the end of the fourteenth century onwards, with an increasing number of universities, which were tied more closely to their immediate environment and depended more on regional powers and local social networks, the understanding of lay participation in the debate about the right path to salvation gradually changed. It became more sophisticated and better rooted in university theology, increasingly frequently formulated and mediated by university-trained people clerics as well as laymen..$^{30}$

Remarkable evidence of the rulership representation conducted at both courts is contained in the textual and iconographic production concerning the visit of Charles IV and Wenceslas IV in France in 1377-1378. See, on this, Šmahel, Journey of Emperor Charles IV. 
A hundred years before the Reformation in the first half of the sixteenth century decided to spread its teaching in vernaculars to highlight the breach with the Catholic-Papal church, the academic Wycliffite heresy of the Czech masters at the University of Prague turned to the Czech vernacular to mobilize their followers among the laity, and to put the Church hierarchy represented by the chancellor of the university, the archbishop of Prague, under pressure. Lay participation in the struggle increased with time, and the initial scholarly dispute transformed into a heterodox lay reform movement, which, after twenty years of religious wars, established its own Christian confession in Bohemia. During these years the vernacular religious teaching aimed at lay recipients gradually separated from the Latin sources and models. This by no means straightforward development found its apex in the teaching of the Czech lay theologian Petr Chelčický, a founding figure of the Church of Bohemian Brethren (Unity of the Brethren), which, at the end of the sixteenth century, produced the above-mentioned Bible translation from the original languages.

Active lay participation in the debate on the reformatio ecclesie was an issue throughout Europe. Complex theological as well as ecclesiological works were available in various vernaculars. Especially in the northern Italian city republics, the Netherlands and Flanders, the fixed roles of the clerics as pastors and of the laity as their obedient flock were often reformulated. Lay people took their spiritual education into their own hands. ${ }^{31}$ The production of vernacular books of religious education in the communities of the Devotio moderna movement was, for example, the main task of the lay members. ${ }^{32}$ Thus, they were able to produce hand-written books very quickly and in high numbers. To own religious books in one's own vernacular was a matter of prestige for many people, especially in prosperous late-medieval cities, ${ }^{33}$ not only for the noble military leaders of Hussite troops, who defied crusades organised by the pope and the Roman emperor to solve a problem which the Church elite was not able to cope with by means of theological disputation.

The violent Bohemian reformation nevertheless produced a predictable side effect. In the neighbouring country Poland, which suffered from Hussite raids, the Church officials led by the archbishop of Cracow and the University of Cracow grew extremely suspicious of any clerical or lay activity concerning the religious education of lay people. They devoted enormous efforts to prohibiting any attempts to discuss religious topics in the vernacular, i.e. in Polish. They indeed managed to slow down the production of Polish religious literature significantly for the next hundred years. ${ }^{34}$ We cannot observe any similar effects of the Hussite revolt in neighbouring German-speaking countries, the Austrian duchy and the German principalities. This is due to the language situation - Polish vernacular literacy closely followed Czech literacy, and Czech texts had been received in Poland since the beginning of the fourteenth century and had, to some degree, formed the basis of religious, educative vernacular literature in Polish. The Church officials in Cracow were concerned with good reason: the danger that the "Bohemian heresy" would migrate across the border together with a heterodox body of thought written in the vernacular was indeed high. There was no need to translate the texts in question, the Polish recipients were able to read them in the Czech original.

31 Corbellini and Steckel, Religious field. This article refers to the results of the debate held in the frame of the COST Action IS 1301 »New Communities of Interpretation«.

32 Staubach, Devotio moderna; Staubach, Kirchenreform von unten.

33 Corbellini et al., Discovering the Riches.

34 Kras, Vernacular eulogy.

medieval worlds $\bullet$ No. $11 \cdot 2020 \cdot 2-16$ 


\section{Multilingual Europe}

Research on the relationship of Polish and Czech medieval vernacular literacies is very modest and does not go beyond a shared supposition among the researchers involved. The national(-istic) character of the responsible philologies determined the questions that researchers asked when they interpreted the extant sources. The history of one's own modern language was the most important question in national linguistics, and the question of the originality of one's "own « literary culture was central for the philologies and literary studies. The interests of modern polities which defined the "national« language determined the questions the research had to ask. This is very probably the main reason why the multilingual character of medieval Europe did not receive the attention which it deserves regarding the character of extant textual material. The various ways in which the individual languages influenced each other; the emerging awareness of differences between individual languages and dialects; the role of known or anonymous authors, writers and scribes who shaped the forms of individual medieval languages known to us, and many other issues, have not been sufficiently studied to date. In Latin Europe the absolute majority of translations were made from Latin, the dominant language of elite literacy. Cultural dominance seems to be a general principle if we search for the reasons for the translations from one vernacular into another. This is the case with the presence of French in England, as well as with the presence of German in Bohemia. In European polities, inhabitants of various languages and dialects lived, and often formed communities with an uneven share of economic and/or political power and with more or less distinct identities. These identities were often unstable, but they could be mobilized if any benefit loomed and/or any aspect of immaterial, real or imagined privileges was in danger.

The largest distinct communities with their own languages and identities in Latin Europe were Sephardic and Ashkenazi Jews, Greeks and Arab Muslims. Translation activities in these communities co-shaped the culture of Latin Europe, especially in the high and late Middle Ages, as the university-based understanding of knowledge became an issue of power and prestige. ${ }^{35}$ There are many references to Hebrew and Greek in extant medieval Latin as well as vernacular sermons intended for lay recipients, and often written by university-educated preachers, who, nevertheless, almost certainly had no noteworthy knowledge of either language. The Greek and Hebrew quotations (often present in the expositions on biblical pericopes) had, among other things, the purpose of demonstrating the high level of education of the respective preacher to his flock. ${ }^{36}$ There was, so it seems, a hierarchy of the three "Holy Languages «: in the second half of the fourteenth century, a lay translator of theological tracts into the Czech vernacular characterised Latin as just another language of the people into which St Jerome translated the Bible to make it understandable for lay believers. ${ }^{37}$

35 The rich history of translating societies in medieval Spain is evidenced not only by the translation of the Bible conducted by Jewish translators from Hebrew into Castilian (the Alba Bible). The popular prophetic Vade mecum in tribulation by John of Rupescissa was translated into Castilian several times. There is an Aljamiado version extant and Hebrew translation is evidenced too. See Codita et al., Castilian versions; Lerner, Putative missing Hebrew translation. See also Hebrew translations of Latin theological works: Visi, Latin to Hebrew translations.

37 Rychterová, Autorität und Wahrheitsdiskurs. 
With the increasing quality of a number of universities, Latin literacy indeed lost something of its previous exclusivity. As it grew more common, Latin could increasingly be used as a lingua franca with the help of which various recipients could share texts without the need for translation. "Latin as vernacular ${ }^{38}$ was a phenomenon in late medieval Europe. A genre in which the convergence of Latin and individual vernacular languages happened most often was sermons. Performed in vernaculars but written in Latin with its fixed textual structures, rhetorics, key words, and - most importantly - abbreviations, the sermons were copied across Europe and adapted to the needs of the individual preachers. When it comes to sermons, the number of macaronic texts in which two or even three languages may be found is remarkably high. The Latin in these texts is often adjusted massively to the syntactic structures of the respective vernacular so that a quick translation back and forth would be possible. ${ }^{39}$ The "vernacular revolution" of the late Middle Ages finds here its telling expression. We can regard the Latin translation of the Bible from Greek made by Erasmus of Rotterdam or the works of Lorenzo Valla and his contemporaries, who turned away from medieval Latin to restitute the "lost " prestige of the learned language, as a symbolic end of the entangled history of medieval European vernaculars and Latin. By means of an exclusive command of the classical Latin language, the humanists wished to introduce new hierarchies in the evergrowing stratum of learned men competing for appropriate positions in both Church and secular administrations.

The introduction of the printing press accelerated many developments already present in the European societies: mass (manual) production of (vernacular) books was practised already decades before the first books were printed, because the demand was rising. Diverse groups with a strong religious and/or political agenda (adherents of Devotio moderna, Hussites) understood the power of the written word - and so did the leaders of the Reformation. The codification of the individual languages that accompanied the printing press was an issue too, long before the linguistic interests that the early Reformists displayed in their elaborated translatologic commentaries.

The translating cultures of medieval Latin Europe were much more complex than this short survey of the main traits of the development of vernacular mentalities can show. Although we may observe tempting similarities between European and, for example, South Asian processes of vernacularization already on this rather simple level of comparison, ${ }^{40}$ much research has to be done to understand them better. Our present as well as future clusters in this journal, focusing on medieval translations, aim to contribute to this field with a distinctly transcultural approach. 


\section{References}

Berman, Antoine, Translatio studii et pouvoir royal, La revue PO\&SIE 80 (1997) 190-200.

Borst, Arno, Der Turmbau von Babel: Geschichte der Meinungen über Ursprung und Vielfalt der Sprachen und Völker 1-4 (Stuttgart, 1957-1963).

Burke, Peter and Ronnie Po-Chia Hsia (eds.), Cultural Translation in Early Modern Europe (Cambridge, 2007).

Catto, Jeremy, The Wycliffite Bible: The historical context, in: Elizabeth Solopova (ed.), The Wycliffite Bible: Origin, History and Interpretation. Medieval and Renaissance Authors and Texts 16 (Brill, 2016) 9-26.

Černá, Soňa, Hieronymus-Briefe des Prager Kanzlers und Notars Johann von Neumarkt. Eine kurze Überlieferungsgeschichte. Katalog. Unpublished $\mathrm{PhD}$ thesis (University of Olomouc, 2018).

Codita, Viorica, Robert E. Lerner, Alberto Montaner Frutos and Rosa Vidal Doval, The Castilian versions of the Vade mecum in tribulatione, in: Robert E. Lerner and Pavlína Rychterová (eds.), John of Rupescissa: Vademecum in tribulatione Translated into Medieval Vernaculars. Ricerche, Storia Diers nova: Fonti e studi per la storia del profetismo 4 (Milan, 2019) 209-300.

Corbellini, Sabrina, Margriet Hoogvliet and Bart Ramakers (eds.), Discovering the Riches of the Word: Religious Reading in Late Medieval and Early Modern Europe. Intersections 38 (Leiden, 2015).

Corbellini, Sabrina and Sita Steckel, The religious field during the long fifteenth century: Framing religious change beyond traditional paradigms, Church History and Religious Culture 99 (2019) 303-329.

Eco, Umberto, Experience in Translation (Toronto, 2001).

Geary, Patrick J., Language and Power in the Early Middle Ages (Waltham, MA, 2013).

Goez, Werner, Translatio imperii: Ein Beitrag zur Geschichte des Geschichtsdenkens und der politischen Theorien im Mittelalter und in der frühen Neuzeit (Tübingen, 1958).

Graus, František, Nationale Deutungsmuster der Vergangenheit in spätmittelalterlichen Chroniken, in: Otto Dann (ed.), Nationalismus in vorindustrieller Zeit. Studien zur Geschichte des 19. Jahrhunderts 14 (Munich, 1986) 35-54.

Jakobson, Roman, On linguistic aspects of translation, in: Roman Jakobson (ed.), Selected Writings 2: Word and Language (The Hague, 1971) 260-266.

John of Rupescissa, Vade mecum in tribulatione, ed. Elena Tealdi, intr. Robert E. Lerner and Gian Luca Potestà (Milan, 2015).

John of Rupescissa, Vademecum in tribulatione Translated into Medieval Vernaculars, ed. Robert Lerner and Pavlína Rychterová, Ricerche, Storia Dies nova: Fonti e studi per la storia del profetismo 2 (Milan, 2019).

Kocka, Jürgen and Heinz-Gerhard Haupt, Comparison and beyond: Traditions, scope and perspectives of comparative history, in: Heinz-Gerhard Haupt and Jürgen Kocka (eds.), Comparative and Transnational History: Central European Approaches and New Perspectives (New York, 2009) 1-32.

Kössinger, Norbert, Elke Krotz, Stephan Müller and Pavlína Rychterová (eds.), Anfangsgeschichten/Origin Stories: Der Beginn volkssprachiger Schriftlichkeit in komparatistischer Perspektive/The Rise of Vernacular Literacy in a Comparative Perspective. MittelalterStudien 31 (Paderborn, 2018). 
Kras, Pawel, The vernacular eulogy of John Wyclif by Master Andrzej of Dobczyn: Textual transmission of dissident ideas in fifteenth-century Poland, in: Pavlína Rychterová (eds.), Pursuing a New Order II: Late Medieval Vernacularization and the Bohemian Reformation. The Medieval Translator/Traduire au Moyen Âge 17/2 (Turnhout, 2019) 185-204.

Lerner, Robert, The putative missing Hebrew translation of the Vade mecum, in: Robert E. Lerner and Pavlína Rychterová (eds.), John of Rupescissa: Vademecum in tribulatione Translated into Medieval Vernaculars. Ricerche, Storia Diers nova: Fonti e studi per la storia del profetismo 4 (Milan, 2019) 491-494.

Menne, Mareike, Rezension. Cultural Translation in Early Modern Europe by Peter Burke and Ronnie Po-Chia Hsia. Reviewed in H-Soz-Kult (online, 25th September 2008). Accessed on 4th May 2020: www.hsozkult.de/publicationreview/id/reb-10888.

Mortensen, Lars Boje, Latin as vernacular: Critical Mass and "Librarization« of new book languages, in: Norbert Kössinger, Elke Krotz, Stephan Müller and Pavlína Rychterová (eds.), Anfangsgeschichten/Origin Stories: Der Beginn volkssprachiger Schriftlichkeit in komparatistischer Perspektive/The Rise of Vernacular Literacy in a Comparative Perspective. MittelalterStudien 31 (Paderborn, 2018) 71-90.

Müller, Stephan, Die Wiener Schule: Deutsche Texte im Umkreis der Universität Wien im 14. und 15. Jahrhundert, in: Viktor Schwarz and Heidrun Rosenberg (eds.), Wien 1365: Eine Universität entsteht (Vienna, 2015) 162-179.

Odstrčilík, Jan, Translation and transformation of Jan Hus's Czech Sunday Postil, in: Pavlína Rychterová (ed.), Pursuing a New Order II: Late Medieval Vernacularization and the Bohemian Reformation. The Medieval Translator/Traduire au Moyen Âge 17/2 (Turnhout, 2019) 153-184.

Ouy, Gilbert, Humanism and nationalism in France at the turn of the fifteenth century, in: Brian Patrick McGuire (ed.), The Birth of Identities: Denmark and Europe in the Middle Ages (Copenhagen, 1996) 107-125.

Pollock, Sheldon, The Language of the Gods in the World of Men: Sanskrit, Culture, and Power in Premodern India (Chicago, 2006).

Pym, Anthony, Exploring Translation Theories (New York, 2010).

Richter Sherman, Claire, Imaging Aristotle: Verbal and Visual Representation in FourteenthCentury France (Berkeley, 1995).

Rychterová, Pavlína, Autorität und Wahrheitsdiskurs im vernakularen katechetischen Schrifttum im spätmittelalterlichen Böhmen, in: Gian Luca Potestà (ed.), Autorität und Wahrheit: Kirchliche Vorstellungen, Normen und Verfahren (XIII.-XV. Jahrhundert). Schriften des Historischen Kollegs, Kolloquien 84 (Munich, 2012) 113-125.

Rychterová, Pavlína, The chronicle of the so-called Dalimil and its concept of Czech identity, in: Pavlína Rychterová (ed.), Historiography and Identity VI: Competing Narratives of the Past in Eastern Central Europe, 1200c.-160oc. (Turnhout, 2020) (forthcoming).

Rychterová, Pavlína, Old Church Slavonic in Great Moravia and Bohemia: Origins, traditions, interpretations, in: Norbert Kössinger, Elke Krotz, Stephan Müller and Pavlína Rychterová (eds.), Anfangsgeschichten/Origin Stories: Der Beginn volkssprachiger Schriftlichkeit in komparatistischer Perspektive/The Rise of Vernacular Literacy in a Comparative Perspective. MittelalterStudien 31 (Paderborn, 2018) 165-184.

Rychterová, Pavlína, Preaching, the vernacular and the laity, in: Michael VanDussen and Pavel Soukup (eds.), Companion to the Hussites. Brill's Companions to the Christian Tradition 90 (Leiden, 2020) 297-330. 
Rychterová, Pavlína, The vernacular theology of Jan Hus, in: František Šmahel (ed.), A Companion to Jan Hus. Brill's Companions to the Christian Tradition 54 (Leiden, 2015) 170-213. Rychterová, Pavlína and Jan Odstrčilík (eds.), Medieval Translations and their Readership. The Medieval Translator/Traduire au Moyen Âge 18 (Turnhout, forthcoming).

Šmahel, František, The Journey of Emperor Charles IV to France 1377-1378 (Prague, 2015).

Solopova, Elizabeth (ed.), The Wycliffite Bible: Origin, History and Interpretation. Medieval and Renaissance Authors and Texts 16 (Brill, 2016).

Staročeský hlaholský Comestor [The Old Czech Glagolitic Comestor], ed. Ludmila Pacnerová (Staré Město, CZ, 2002).

Staubach, Nikolaus, Die Devotio moderna als Textgemeinschaft, in: Angelika Lehmann-Benz, Ulrike Zellmann and Urban Küsters (eds.), Schnittpunkte: Deutsch-niederländische Literaturbeziehungen im späten Mittelalter (Münster, 2003) 19-40.

Staubach, Nikolaus (ed.), Kirchenreform von unten: Gerhard Zerbolt von Zutphen und die Brüder vom gemeinsamen Leben. Tradition - Reform - Innovation 6 (Frankfurt/Main, 2004).

Torop, Peeter, Translation as translating as culture, Sign Systems Studies 30/2 (2002) 593604.

Van Engen, John, Multiple options: The world of the fifteenth-century church, Church History 77 (2008) 257-284.

Visi, Tamas, Latin to Hebrew translations in late medieval Ashkenaz: Two different strategies, in: Rychterová, Pavlína (ed.), Pursuing a New Order I: Religious Education in Late Medieval Central and Eastern Central Europe. The Medieval Translator/Traduire au Moyen Âge 17/1 (Turnhout, 2018) 75-90.

Woodsworth, Judith and Gillian Lane-Mercier, Introduction: Translation as a master metaphor, in: Judith Woodsworth (ed.), The Fictions of Translation (Amsterdam, 2018) 1-14.

Zironi, Alessandro, Gothic texts: Translations, audience and readers, in: Pavlína Rychterová and Jan Odstrčilík (eds.), Medieval Translations and their Readership. The Medieval Translator/Traduire au Moyen Âge 18 (Turnhout, forthcoming).

Žůrek, Václav and Pavlína Rychterová, Slavonic and Czech identity in the Chronicon Bohemiae by Přibík Pulkava of Radenín, in: Pavlína Rychterová (ed.), Historiography and Identity VI: Competing Narratives of the Past in Eastern Central Europe, 1200c.-160oc. (Turnhout, 2020) (forthcoming). 